\title{
Genetic diversity analysis of Gaeumannomyces graminis var. tritici in Kermanshah Province of Iran using RAPD markers
}

\author{
Yosefvand $\mathrm{M}^{1 *}$, Abbasi $\mathrm{S}^{1}$, Chagha-Mirza $\mathrm{K}^{2}$, Bahram-Nezhad $\mathrm{S}^{2}$ \\ Department of plant protection, university of Razi, Kermanshah, Iran \\ Department of Agronomy and Plant Breeding, university of Razi, Kermanshah, Iran
}

Yosefvand M, Abbasi S, Chagha-Mirza K, Bahram-Nezhad S 2016 - Genetic diversity analysis of Gaeumannomyces graminis var. tritici in Kermanshah Province of Iran using RAPD markers. Plant Pathology \& Quarantine 6(2), 207-218, Doi 10.5943/ppq/6/2/9

\begin{abstract}
Take-all disease caused by Gaeumannomyces graminis is the most destructive disease on cereals in the world that has been reported from different areas in Iran. Ninety-seven isolates were obtained from diseased plants collected from Kermanshah Province. To evaluate the genetic diversity 60 isolates were selected and studied using RAPD molecular finger-print. All samples were collected during 2010 and 2011 summer. RAPD-PCR was carried out to investigate genetic diversity. Fifteen RAPD primers which had more polymorphism and higher repeatability were used for DNA replication. The dendrogram obtained from cluster analysis of isolates divided strains into eight groups at the similarity level of $32 \%$. This grouping was somewhat according to the geographical distribution. The polymorphism obtained for RAPD markers was calculated as $100 \%$. To ensure the correct identification of isolates, specific primers were used to identify varieties of G. g. var. tritici, G. g. var. avenae and G. g. var. graminis. These primers did not replicate any DNA fragment for G. g. var. graminis varieties. The results showed that specific primers are sensitive and useful for identification of different varieties of G. graminis. This is the first report of using RAPD markers to assess genetic variation of G. graminis in Iranian isolates isolated from wheat and barley.
\end{abstract}

Key words - geographical distributions - Iranian varieties - molecular finger-print - take all

\section{Introduction}

Take-all disease caused by Gaeumannomyces graminis var. tritici is a fungal disease of wheat that starts as a root rot, causing stunting and nutrient deficiency-like symptoms in the tops, and progressing upward into the base of the stems where it can then disrupt the flow of water to the tops and cause premature death of the plant (Cook 2003, Elliott \& Landschoot et al. 1991). Take-all is the second most destructive disease of wheat in the world (Trolldenier et al. 1981). It was first reported as a disease of wheat in Sweden in 1823 (Nilsson et al. 1969). In Iran, it was first reported from Dasht naz farms in Sari and also in other regions of Mazandaran and Gorgan provinces (Forotan et al. 1989). The disease is now present in most regions of Iran (Safaei et al. 2007). In some infected farms up to $80 \%$ loss of crop has been estimated (Kazemi et al. 2008). The genus Gaeumannomyces contains seven species that have different hosts (Freeman \& Ward 2004, 
Rachdowang et al. 1999). Gaeumanomyces graminis is the most important species in the genus. This species is divided into four varieties: G. graminis var. tritici (Ggt), G. graminis var. avenae (Gga), G. graminis var. maydis (Ggm) and G. graminis var. graminis (Ggt). G. graminis var. tritici is the major agent of take-all that also infects barely but not oats. G. graminis var. avenae additionally causes disease on oat. G. graminis var. maydis causes disease on corn and G. graminis var. graminis attacks some grass weeds, including Bermuda grass and rice (Freeman \& Ward 2004, Fouly et al. 1996).

Host range, vast geographical spread, viability and complexity of soil environment have led to inefficient chemical control and difficulty in managing this disease. Many ways to control and contain the disease have been recommended including removing plant debris and weeds, use of symbiotic microorganism, deep tillage, chemical control, use of resistant varieties and crop rotation (Tilson 2005, Mathre 1998, Mathre 1992, Cook et al. 2003).

The aim of this study is to recognize G. graminis var. tritici strains in wheat and barley in Kermanshah Province and also to investigate the amount of genetic diversity from 14 different areas of Kermanshah Province using RAPD-PCR molecular markers.

\section{Materials \& Methods}

\section{Sampling}

During 2010 and 2011, sampling of infected plants from Kermanshah, Dalahoo, Salas, Eslam abad, Giulan gharb, Sarpol-e Zahab, Ravansar, Javanrud and other cities were conducted. After removing excess plant parts infected samples were placed inside a paper bag and transported to the laboratory.

\section{Isolation of pathogen}

Segments of infected plant tissues were washed under tap water for 10 minutes. The washed segments were sliced into smaller pieces and surface sterilized by dipping in $1 \%$ sodium hypochlorite for one minute. The surface sterilized pieces were placed on $2 \%$ water agar and $2 \%$ potato dextrose agar (PDA) and then incubated at $25{ }^{\circ} \mathrm{C}$ for 10 days. Spores generated on surface sterilized leaves at $25{ }^{\circ} \mathrm{C}$, were transferred to $2 \%$ water agar and then fungal colonies were produced by hyphal tip method on PDA (Freeman \& Ward et al. 2004). Ninety-seven G. graminis isolates were selected according to geographical distribution and were used in this study (Table 1).

\section{Identification of isolates}

Preliminary detection of pathogen isolates was done due to the characteristics of colony morphology, growth pattern and form of mycelium branches and also according to the ability to produce perithecia on agar medium containing germinated seeds of wheat, wheat extract and stems and pods extract of bean plants (Crozier 1999, Holden \& Hornby 1981, Thomas et al. 2004). The production of hyphopodia was also studied (Fig. 1). However, the specific primer was used to ensure correct identification of isolates.

DNA was extracted from 97 fungal isolates following the protocol outlined by Thomas et al. (2004). Then, reverse PCR primers GGT-RP and GGA-RP, with NS5 (White et al. 1990) as the forward primer was used for identification of G. graminis isolates (Fouly \& Wilkinson et al. 2000). Amplification by NS5/GGT-RP can distinguish between isolates of Ggt and isolates of Gga on the basis of PCR product size.

PCR primers GG1 and GG2 were designed for diagnosis of take-all patch of turf-grasses (Goodwin et al. 1995). Three isolates of Rhizoctonia sp., Fusarium sp. and Pythium sp. as a negative control were used in this test. They were amplified with primers NS5: 5' AACTTAAAGGAATTGACGGAAG 3' and GT-RP:5' TGCAATGGCTTCGTGAA 3', (GGA-RP: 5' TTTGTGTGTGACCATAC 3), respectively, in a $25 \mathrm{ml}$ reaction containing 1 units Taq DNA polymerase, $2 / 5 \mu \mathrm{l}$ PCR buffer provided by the manufacturer, $1 / 6 \mu 1 \mathrm{MgCl}_{2}, 10 \mathrm{mM}$ each dNTP, $1 / 5 \mu \mathrm{l}$ each primer and $10 \mathrm{ng}$ template DNA, using a thermocycler (Corbett Research, Australia) 
programmed for $3 \mathrm{~min}$ at $93{ }^{\circ} \mathrm{C}, 30$ cycles of $35 \mathrm{~s}$ at $93{ }^{\circ} \mathrm{C}, 60 \mathrm{~s}$ at $52{ }^{\circ} \mathrm{C}$, and $1 \mathrm{~min}$ at $72{ }^{\circ} \mathrm{C}$, followed by $5 \mathrm{~min}$ at $72{ }^{\circ} \mathrm{C}$ (Fouly \& Wilkinson et al. 2000a). Electrophoresis of PCR products with voltage 120 and for an hour in agarose gel $4.1 \%$ was done. After completion of electrophoresis, the gels were placed in ethidium bromide solution $(0 / 5 \mu \mathrm{g} / \mathrm{ml})$ for 20 minutes. Shooting with UVP gel imaging system was conducted.

\section{RAPD PCR}

According to host variety and geographical distribution, 60 isolates were selected and the genetic diversity of these analyzed using RAPD technique. Of the 20 RAPD primers that were tested initially, 15 primers which showed greater repeatability and polymorphism were used to test all isolates (Table 2). For the RAPD primer pairs PCR assays were done in a total volume of $25 \mu 1$ with a final concentration of $2.5 \mu 1$ of XPCR buffer, $0.5 \mu 1$ of each dNTP $(10 \mathrm{mM}), 1.6 \mu 1 \mathrm{MgCl} 2$, $0.2 \mu \mathrm{l}$ of Taq (1U) DNA polymerase, $2.5 \mu \mathrm{l}$ of each primer $(10 \mu \mathrm{M})$ and approximately $2.5 \mu \mathrm{l}$ of fungal template DNA $(10 \mathrm{ng} / \mu \mathrm{l})$ were used. Reactions were performed in a CORBETT Research model thermal cycler using the following PCR conditions: denaturation at $95{ }^{\circ} \mathrm{C}$ for $5 \mathrm{~min}, 35$ cycles of denaturation at $94{ }^{\circ} \mathrm{C}$ for $40 \mathrm{sec}$, annealing at $40{ }^{\circ} \mathrm{C}$ for $50 \mathrm{sec}$, extension at $72{ }^{\circ} \mathrm{C}$ for 1 min, final extension at $72{ }^{\circ} \mathrm{C}$ for $5 \mathrm{~min}$, followed by cooling at $4{ }^{\circ} \mathrm{C}$ until recovery of the samples. Amplification products were visualized in $1.2 \%$ agarose gels stained with ethidium bromide (Mule et al. 2004).

\section{Statistical analysis}

Due to use of the specific markers to identify varieties it can be separated from the other variety by produced band during RAPD PCR, so the electrophorese gels can be scored by existence (1) or not existence (0) of the bands on the gel in this method. Cluster analysis was done by WPGMA method, Jaccard index and MVSP ver. 3.131, NTSYSpc ver. 2.02, GenAlex ver. 6.1 software programs (Peakall \& Smouse 2006). For the two-dimensional observation of distance between the isolates, principal component analysis was used to supplement the clustering method.

Table 1 Information of infected samples collected from different parts of Kermanshah.

\begin{tabular}{|c|c|c|c|c|c|c|c|}
\hline Code & Location & Host & $\begin{array}{l}\text { Culture } \\
\text { mode }\end{array}$ & Code & Location & Host & $\begin{array}{c}\text { Culture } \\
\text { mode }\end{array}$ \\
\hline $\mathrm{G} 1=1 *$ & Sare pol Zahab & Wheat & Irrigated & $\mathrm{G} 50=26 *$ & $\begin{array}{l}\text { Ravansar- } \\
\text { Pave }\end{array}$ & Barely & Rain-fed \\
\hline $\mathrm{G} 2$ & Salas Babajani & Wheat & Rain-fed & G51 & Javanrood & Barely & Rain-fed \\
\hline $\mathrm{G} 3=2 *$ & Sare pol Zahab & Wheat & Irrigated & G52 & Javanrood & Barely & Rain-fed \\
\hline G4 & Gilan Gharb & Barely & Rain-fed & $\mathrm{G} 53=27 *$ & Koozaran & Barely & Rain-fed \\
\hline $\mathrm{G} 5=3 *$ & Gilan Gharb & Barely & Rain-fed & $\mathrm{G} 54=28 *$ & Koozaran & Barely & Rain-fed \\
\hline G6 & Gilan Gharb & Barely & Rain-fed & $\mathrm{G} 55=29 *$ & Koozaran & Barely & Rain-fed \\
\hline G7 & Gilan Gharb & Barely & Rain-fed & $\mathrm{G} 56=30 *$ & Koozaran & Barely & Rain-fed \\
\hline $\mathrm{G} 8=4 *$ & Gilan Gharb & Wheat & Rain-fed & G57 & Koozaran & Barely & Rain-fed \\
\hline $\mathrm{G} 9=5^{*}$ & Gilan Gharb & Wheat & Rain-fed & G58 & Koozaran & Barely & Rain-fed \\
\hline G10 & Faraman village & Barely & Rain-fed & G59 & Koozaran & Barely & Rain-fed \\
\hline $\mathrm{G} 11=6^{*}$ & Negivaran & Barely & Rain-fed & $\mathrm{G} 60=31 *$ & Javanrood & Barely & Rain-fed \\
\hline G12 & Ghazanchi & Barely & Rain-fed & G61 & Koozaran & Barely & Rain-fed \\
\hline $\mathrm{G} 13=7 *$ & Ghazanchi & Barely & Rain-fed & G62 & Koozaran & Barely & Rain-fed \\
\hline G14 & Ghazanchi & Barely & Rain-fed & $\mathrm{G} 63=32 *$ & Mahidasht & Barely & Rain-fed \\
\hline $\mathrm{G} 15=8 *$ & Ghazanchi & Barely & Rain-fed & $\mathrm{G} 64=33^{*}$ & Bistoon & Wheat & Irrigated \\
\hline $\mathrm{G} 16=9 *$ & Ghazanchi & Barely & Rain-fed & $\mathrm{G} 65=34 *$ & Bistoon & Wheat & Irrigated \\
\hline G17 & Ghazanchi & Barely & Rain-fed & $\mathrm{G} 66=35^{*}$ & Bistoon & Wheat & Irrigated \\
\hline G18 & Ghazanchi & Barely & Rain-fed & $\mathrm{G} 67=36^{*}$ & Bistoon & Wheat & Irrigated \\
\hline
\end{tabular}


Table1 (continued)

\begin{tabular}{|c|c|c|c|c|c|c|c|}
\hline Code & Location & Host & $\begin{array}{c}\text { Culture } \\
\text { mode }\end{array}$ & Code & Location & Host & Culture mode \\
\hline G19 & Ghazanchi & Barely & Rain-fed & $\mathrm{G} 68=37 *$ & Bistoon & Wheat & Irrigated \\
\hline $\mathrm{G} 20=10 *$ & Ghazanchi & Barely & Rain-fed & G69 & Bistoon & Wheat & Irrigated \\
\hline $\mathrm{G} 21=11 *$ & Ghazanchi & Wheat & Irrigated & G61 & Bistoon & Wheat & Irrigated \\
\hline G22 & Ghazanchi & Wheat & Irrigated & G70 & Harsin & Wheat & Irrigated \\
\hline $\mathrm{G} 23=12 *$ & Sarab Ghanbar & Barely & Rain-fed & $\mathrm{G} 71=28 *$ & Harsin & Wheat & Irrigated \\
\hline $\mathrm{G} 24=13 *$ & Sarab Ghanbar & Barely & Rain-fed & $\mathrm{G} 72=39 *$ & Harsin & Wheat & Irrigated \\
\hline $\mathrm{G} 25=14 *$ & Sarab Ghanbar & Barely & Rain-fed & $\mathrm{G} 73=40 *$ & Harsin & Wheat & Irrigated \\
\hline G26 & Sarab Ghanbar & Barely & Rain-fed & $\mathrm{G} 74=41 *$ & Harsin & Wheat & Rain-fed \\
\hline $\mathrm{G} 27=15^{*}$ & Sarab Ghanbar & Barely & Rain-fed & $\mathrm{G} 75=42 *$ & Mahidasht & Wheat & Irrigated \\
\hline G28 & Sarab Ghanbar & Barely & Rain-fed & G76 & Mahidasht & Wheat & Irrigated \\
\hline $\mathrm{G} 29=16^{*}$ & Sarab Ghanbar & Barely & Rain-fed & $\mathrm{G} 77=43 *$ & Mahidasht & Barely & Rain-fed \\
\hline G30 & Sarab Niloofar & Wheat & Irrigated & $\mathrm{G} 78=44 *$ & Eslam Abad & Barely & Rain-fed \\
\hline $\mathrm{G} 31=17 *$ & Sarab Niloofar & Barely & Rain-fed & $\mathrm{G} 79=45^{*}$ & Sahne & Wheat & Irrigated \\
\hline $\mathrm{G} 32=18 *$ & Sarab Niloofar & Wheat & Irrigated & $\mathrm{G} 80=46^{*}$ & Faraman & Barely & Rain-fed \\
\hline $\mathrm{G} 33=19 *$ & Koozaran & Barely & Rain-fed & $\mathrm{G} 81=47 *$ & Faraman & Wheat & Rain-fed \\
\hline G34 & Koozaran & Barely & Rain-fed & $\mathrm{G} 82=48 *$ & Faraman & Wheat & Rain-fed \\
\hline G35 & Koozaran & Barely & Rain-fed & $\mathrm{G} 83=49 *$ & Faraman & Barely & Rain-fed \\
\hline $\mathrm{G} 36=20 *$ & Koozaran & Barely & Rain-fed & $\mathrm{G} 84=50^{*}$ & Faraman & Barely & Rain-fed \\
\hline $\mathrm{G} 37=21 *$ & Koozaran & Barely & Rain-fed & $\mathrm{G} 85=51 *$ & Mian Rahan & Barely & Rain-fed \\
\hline $\mathrm{G} 38=22 *$ & Koozaran & Barely & Rain-fed & G86 & Mian Rahan & Barely & Rain-fed \\
\hline G39 & Koozaran & Barely & Rain-fed & $\mathrm{G} 87=52 *$ & Songhor & Barely & Rain-fed \\
\hline G40 & Koozaran & Barely & Rain-fed & $\mathrm{G} 88=53 *$ & Songhor & Barely & Rain-fed \\
\hline G41 & Koozaran & Barely & Rain-fed & $\mathrm{G} 89=54^{*}$ & Songhor & Barely & Rain-fed \\
\hline $\mathrm{G} 42=23 *$ & Koozaran & Barely & Rain-fed & $\mathrm{G} 90=55^{*}$ & Kerend & Wheat & Irrigated \\
\hline $\mathrm{G} 43=24 *$ & Koozaran & Barely & Rain-fed & G91=56* & Kerend & Wheat & Irrigated \\
\hline G44 & Koozaran & Barely & Rain-fed & $\mathrm{G} 92=57 *$ & Gilan Gharb & Barely & Rain-fed \\
\hline G45 & Koozaran & Barely & Rain-fed & $\mathrm{G} 93=58 *$ & Gilan Gharb & Wheat & Rain-fed \\
\hline G46 & Koozaran & Barely & Rain-fed & G94 & Gilan Gharb & Wheat & Rain-fed \\
\hline $\mathrm{G} 47=25^{*}$ & Koozaran & Barely & Rain-fed & G95 & Kamiaran & Wheat & Rain-fed \\
\hline G48 & Koozaran & Barely & Rain-fed & $\mathrm{G} 96=59 *$ & Pave & Wheat & Irrigated \\
\hline G49 & Ravansar-Pave & Barely & Rain-fed & G97 $=60 *$ & Eslam Abad & Wheat & Irrigated \\
\hline
\end{tabular}

* Selected isolates used in the study of genetic diversity.

Table 2 Details of the primers used to assess genetic diversity of Gaeumannomyces graminis.

\begin{tabular}{llc}
\hline \multicolumn{1}{c}{ Primer } & Sequence 5'-3' & $\begin{array}{c}\text { Annealing } \\
\text { temperature } \\
{ }^{\circ} \mathbf{C}\end{array}$ \\
\hline OPC07 & GTCCCGACGA & 40 \\
E10 & CACCAGGTGA & 40 \\
U11 & AGACCCAGAG & 40 \\
A7 & GAAACGGGTG & 40 \\
OPC13 & AAGCCTCGTC & 40 \\
E17 & CTACTGCCGT & 40 \\
OPC10 & TGTCTGGGTG & 37 \\
E16 & GGTGACTGTG & 40 \\
ABI & CCGTCGGTAG & 40 \\
OPC04 & CCGCATCTAC & 40 \\
E7 & AGATGCAGCC & 40 \\
E19 & ACGGCGTATG & 40 \\
C16 & CACACTCCAG & 40 \\
OPC15 & GACGGATCAG & 40 \\
OPC08 & TGGACCGGTG & 40 \\
\hline
\end{tabular}




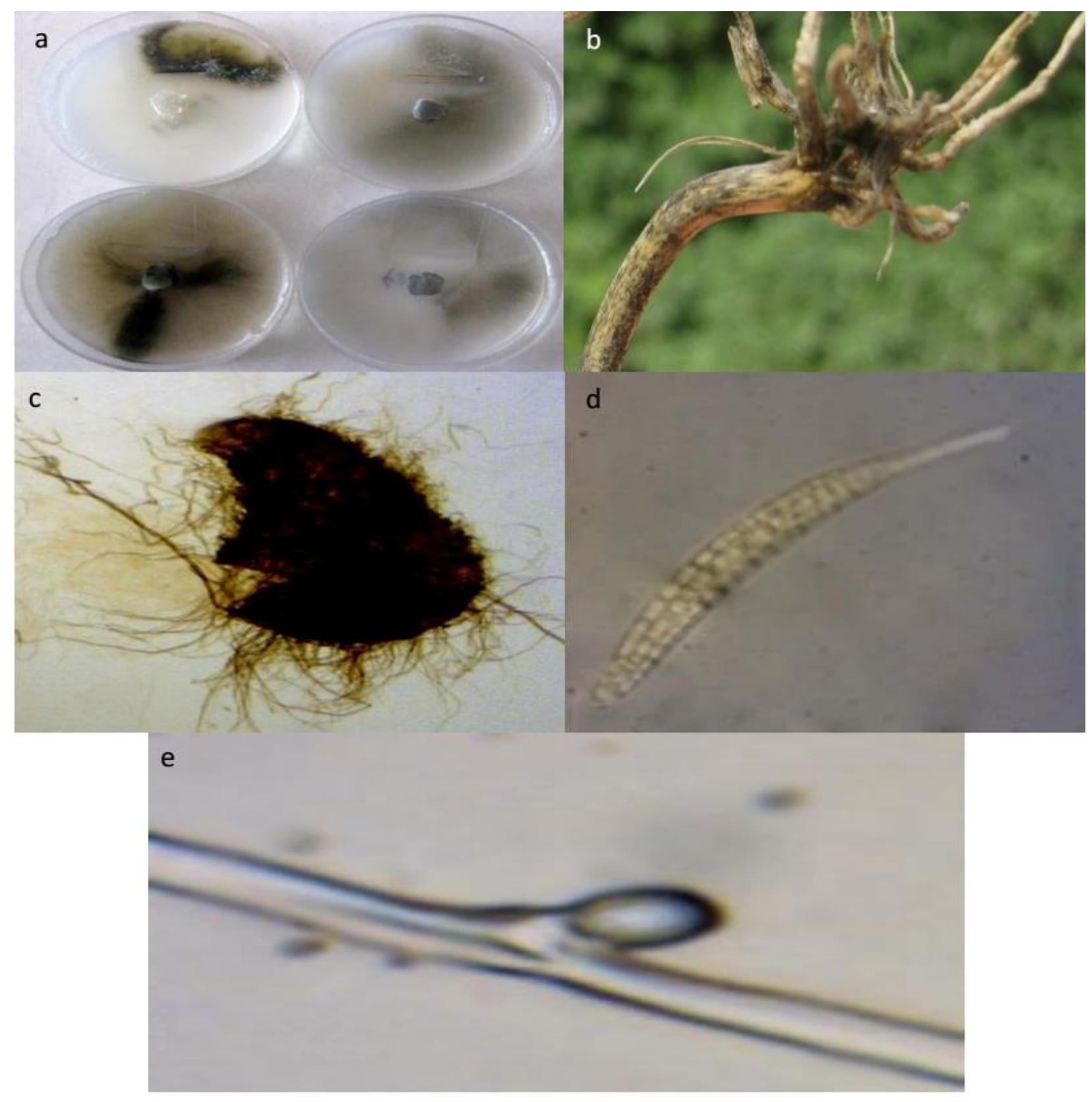

Fig 1 - Morphological characters of Gaeumannomyces graminis var. tritici. a. Morphological variety of colony appearance in different isolates of Gaeumannomyces graminis var. tritici at $25^{\circ}$ on PDA. b. Black stolon of Gaeumannomyce graminis var. tritici on rotted wheat root. c, d. Asci and ascospores exiting from perithecia. e. Moving hypha with simple hyphopodium.

\section{Results}

The presence of G. graminis was found in 139 out of 307 farms visited. For all isolates, application of upstream NS5 primer with downstream GGT-RP primer lead to a band in the range of $410 \mathrm{bp}$ and the application of upstream NS5 primer with downstream GGA-RP primer lead to a band in the range of $400 \mathrm{bp}$. The results in both cases showed that all isolates were G. $g$. var. tritici. The use of both downstream primers was done in the presence of three witnesses, including Pythium sp., Rhizoctonia sp. and Fusarium sp. The results showed that $G$. g. var. avenae was not found among collected isolates and all isolates belong to varieties G. g. var. tritici (Fig. 2). 


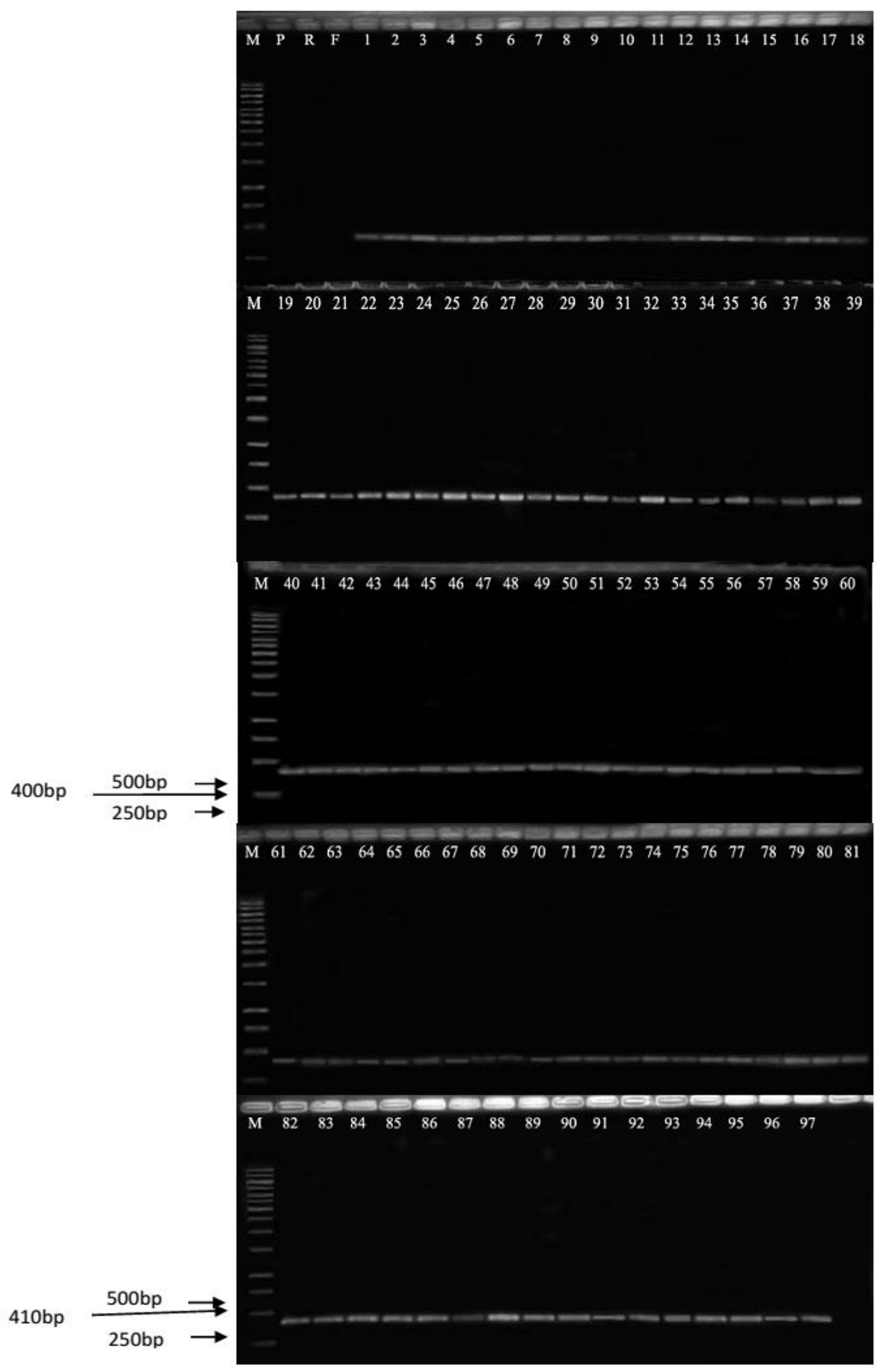

Fig 2 - Banding patterns attained from 97 selected isolates of Gaeumannomyces graminis using specific primers, with control. M: $1 \mathrm{~kb}$ molecular marker. 


\section{Analysis of DNA fingerprinting RAPD PCR}

Out of 20 tested RAPD primers, 15 primers showed a greater repeatability and polymorphism, thus they were used for all strains (Fig. 3).

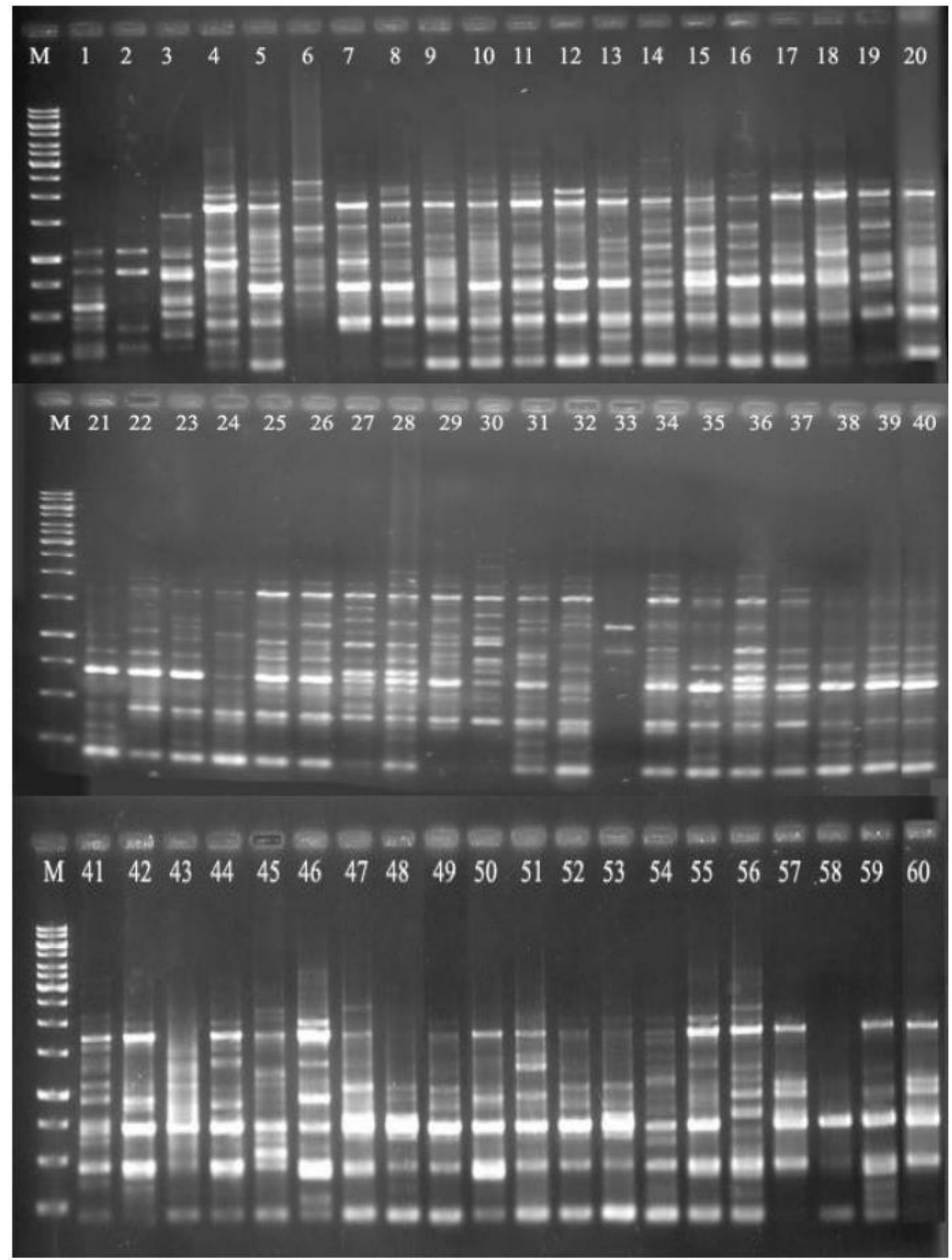

Fig 3 - Banding patterns attained from 60 selected isolates of Gaeumannomyces graminis isolated from wheat and barley using primer E7. M: $1 \mathrm{~kb}$ molecular marker. 
The number and range of bands produced by each primer is shown in Table 3 . The results of the analysis of the banding pattern of all RAPD primers divided the isolates into eight groups, in similarity level of $32 \%$, also confirmed by two-dimensional plot obtained from the main coordinate analysis (Figs 4, 5).

Table 3 Percentage of the polymorphism and information content of 15 primers used for 60 isolates of Gaeumannomyces graminis.

\begin{tabular}{llllll}
\hline Primer & PIC $^{\mathbf{1}}$ & $\mathbf{M I}^{\mathbf{2}}$ & Total bands & $\begin{array}{l}\text { Number of } \\
\text { polymorphic } \\
\text { bands }\end{array}$ & $\begin{array}{l}\text { Polymorphism } \\
\text { percentage }\end{array}$ \\
\hline OPC07 & 33.0 & 95.6 & 21 & 21 & 100 \\
E10 & 38.0 & 09.8 & 21 & 21 & 100 \\
U11 & 42.0 & 72.6 & 16 & 16 & 100 \\
A7 & 34.0 & 6.6 & 19 & 19 & 100 \\
OPC13 & 30.0 & 15.6 & 20 & 20 & 100 \\
E17 & 27.0 & 15.5 & 19 & 19 & 100 \\
OPC10 & 33.0 & 66.4 & 14 & 14 & 100 \\
E16 & 34.0 & 49.7 & 22 & 22 & 100 \\
ABI & 38.0 & 14.6 & 16 & 16 & 100 \\
OPC04 & 38.0 & 53.8 & 22 & 22 & 100 \\
E7 & 38.0 & 57.9 & 25 & 25 & 100 \\
E19 & 33.0 & 07.6 & 18 & 18 & 100 \\
C16 & 34.0 & 04.8 & 23 & 23 & 100 \\
OPC15 & 36.0 & 74.9 & 27 & 27 & 100 \\
OPC08 & 36.0 & 57.9 & 21 & 21 & 100 \\
Average & 34.0 & 23.7 & 304 & 304 & \\
1- Polymorphic Information Content & & & & & \\
2- Marker Index & & & & &
\end{tabular}

Three hundred and four loci were obtained from all RAPD band patterns, all of which had polymorphism. Maximum and minimum polymorphic loci were attained using OPC 15 primer (27 loci) and OPC 10 primer (14 loci), respectively. Among these primers, OPC 15 primer was allocated the highest ability of separation. Maximum and minimum amount PIC was 0.42 belonging U11 primer and 0.27 belonging E11 primer. The average of calculated PIC was 0.34 . High levels of PIC in this study show the high level of distinction. Marker index were calculated on the basis of polymorphic bands per primer and was variable from 4.66 to 9.74 which belonging OPC 10 primer and OPC 15 primer, respectively. The results showed that the highest and lowest genetic similarity based on Jaccard coefficient was between isolate 1 from sarpol-e Zahab (wheat) and isolate 2 sarpol-e Zahab (wheat) in amount of 53/0 and between isolate 22 from Kuzaran (barley) and isolate 56 from Islamabad (barley) in amount of 18/0. Attained results of RAPD cluster analysis did not match with the geographical location. Cophenetic coefficient was calculated at a rate of 527/0, for obtained results of RAPD analysis. 


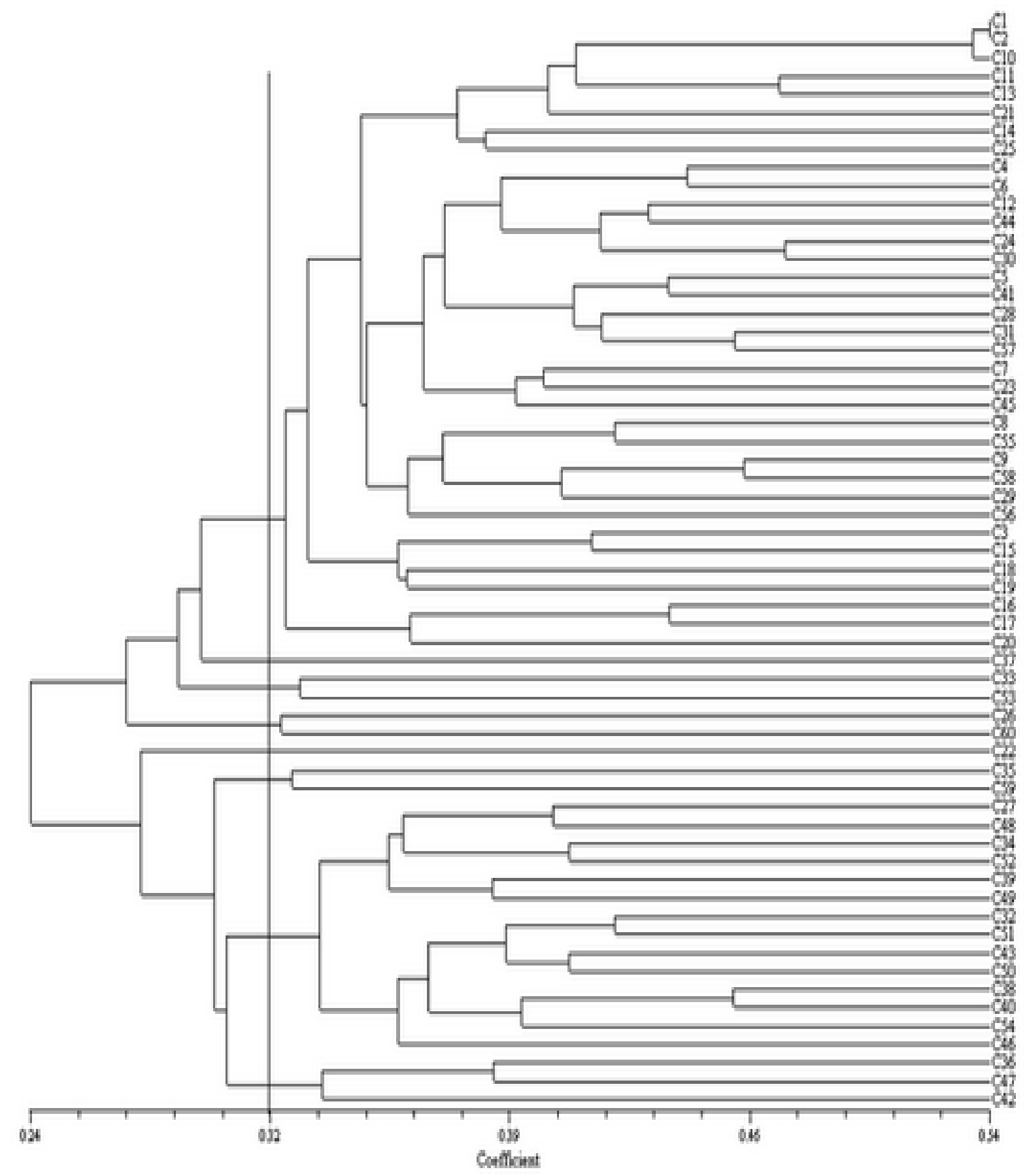

Fig 4 - Dendrogram based on UPGMA using combined data from RAPD banding patterns.

\section{Discussion}

The results of this research confirm effectiveness of DNA fingerprinting using RAPD markers and use of specific primers to identify the fungus G. graminis. Conventional identification of G. graminis is time consuming and unreliable, and differences in the medium materials can lead to uncertain identification of fungus and its varieties (Asher \& Shipton 1981). Because of the similarity of morphological and reproductive characteristics, it is difficult to distinguish varieties $G$. g. var. tritici and $G$. g. var. avenae, despite the use of morphological and reproductive characteristics such as stolon and size of ascospores in identification process. Although the pathogenicity test is not easy because of its long and time-consuming process. In general, use of proprietary medium can distinguish varieties of G. graminis, but these methods are costly. Since this fungus is destructive and difficult to control. An accurate, rapid and sensitive method which 


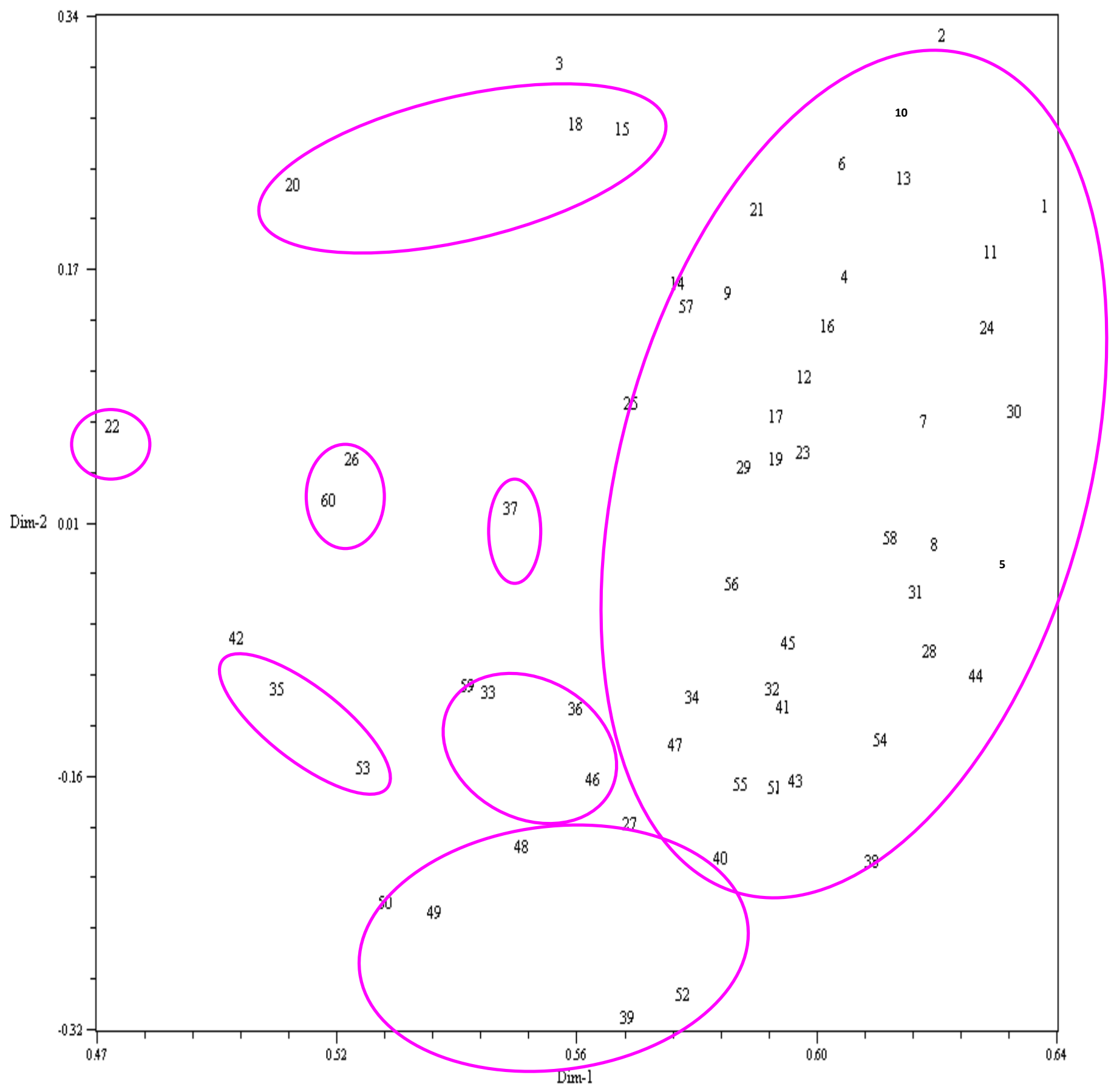

Fig 5 - Two-dimensional plot of the original coordinate analysis using Jaccard matrix for 60 selected isolates of Gaeumannomyces graminis.

cans diagnosis the fungus even in soil and plant tissue is necessary. In addition to the differentiation of $G$. graminis from other species, species-specific primers can also separate varieties $G$. g. var. tritici from G. g. var. graminis and G. g. var. avenae. So, in order to ensure the correct identification of obtained isolates, specific primers were used to separate $G$. $g$. var. tritici varieties from G. g. var. graminis and G. g. var. avenae varieties. In PCR progress NS5: GGT-Rp and NS5: GGA-RP were used as specific primers. The results showed that 97 studied isolates were G. $g$. var. tritici, according to production of 410 and $400 \mathrm{bp}$ bands by this isolate. As well as the results it can be deduced that, no observation of band $300 \mathrm{bp}$ between the produced bands indicate the lack of variety G. g. var. avenae among the isolates. All tests were conducted in the presence of three controls (Fusarium sp., Rhizoctonia sp., Pythium sp.) for which no band was attained (Fig. 1). 
These results confirm the results of other researchers (Irzykowska 2007, Thomas 2004, Fouly \& Wilkinson 1999, White et al. 1990). Specific primers used in this study, do not produce any bands for G. g. var. graminis., according to Fouly \& Wilkinson (2000). To study the genetic diversity of G. graminis, 60 isolates were selected from the 97 isolates and were analyzed by RAPD markers. The polymorphism amount attained for each primer was equal to 100 percent. The results of this study demonstrate that RAPD marker is a good marker for studying genetic diversity of $G$. graminis isolates. For example, Augustin et al. (1999) used 26 different RAPD primers to study 48 isolates of $G$. graminis by analyzing of lac or existence of bands and they can classify the isolates into four groups. According to host and geographical location, Weber et al. (2005) classified 70 isolate of $G$. graminis, isolated from wheat, into two main groups by using 10 different RAPD markers. The results showed that, high diversity level was observed among the isolates and also cluster analysis of RAPD markers was partly consistent with the geographical distribution of the isolates. This study suggests that locating the isolates from different regions in a same group indicates their genetic similarity. This study identified considerable variation among isolates of $G$. graminis, and also isolates grouped by geographical origin can be due to pathogen transmission and since the fungus is soil-born it can spread by agricultural implements or irrigation water through the soil to other areas, thus creating strains with the same genetic pattern from different areas of the province. The results showed that the vast genetic diversity in this species have seen, not only among isolates with distinct geographical areas but also in the population of isolates collected from a plant host and even in isolate from same region. This study also produces considerable information in relation to identification and genetic diversity of Iranian isolates of G. graminis through specific primers and RAPD molecular markers. In the case of an opportunistic disease, high genetic diversity helps it to survive in nature. So, the assessment of genetic diversity of Iranian strains of G. graminis made understanding the pathogen population structure easier and as a result can impact disease management.

\section{References}

Asher MJC, Shipton PJ. 1981 - Biology and control of take-all. Academic Press, London, pp. 538.

Augustin C, Ulrich K, Ward E, Weber A. 1999 - RAPD-based inter and intravarietal classification of fungi of Gaeumannomyces-Phialophora complex. Journal of Phytopathology 147, $109-117$.

Cook RJ. 2003 - Take-all of wheat. Physiological and Molecular Plant Pathology 62, 73-86.

Crozier JB. 1999 - Evaluation of agents for the suppression of take-all of wheat in Virginia in green house and field studies and characterization of isolates of Gaeumannomyces graminis varieties. Ph.D. Dissertation. Virginia Polytechnic Institute and State University, Blacksburg, UA, USA.

Elliott ML, Landschoot PJ. 1991 - Fungi similar to Gaeumannomyces associated with root rot of turf grasses in Florida. Plant Disease Journal 75, 238-241.

Forotan A. 1989 - Take-all disease in Gorgan and Mazandaran provinces. Plant pest and pathogens pp. 59-61. (In Persia).

Fouly HM, Wilkinson HT. 1999 - Use of RAPD markers as a diagnostic tool in the identification of Gaeumannomyces graminis isolates that cause patch diseases of grasses. Journal of Plant Pathology 81, 103-111.

Fouly HM, Wilkinson HT. 2000 - Detection of Gaeumannomyces graminis varieties using polymerase chain reaction with variety-specific primers. Plant Disease Journal 84, 947-951.

Fouly HM, Wilkinson HT, Domier LL. 1996 - Use of random amplified polymorphic DNA (RAPD) for identification of Gaeumannomyces species. Journal of Environmental Science and Natural Resources 28(6), 703-710.

Freeman J, Wade E. 2004 - Gaeumannomyces graminis, the take-all fungus and its relatives. Molecular Plant Pathology 5(4), 235-252. 
Goodwin PH, Hsiang T, Xue BG, Liu HW. 1995 - Differentiation of Gaeumannomyces graminis from other turf-grass fungi by amplification with primers from ribosomal internal transcribed spacers. Plant Pathology 44, 384-391.

Holden M, Hornby D. 1981 - Methods of producing of Gaeumannomyces graminis and their application to related fungi. Transactions of the British Mycological Society 77, 107-118.

Irzykowska L. 2007 - Molecular detection and comparison of Gaeumannomyces graminis var. tritici isolates originating from wheat and rye. Journal of Plant Protection Research 47(3), 299-308.

Kazemi H, Azad-bakht N, Mobaraki D. 2008 - Appearance of take-all disease in Lorestan province. Eighteenth Congress of Plant Protection, Iran. pp. 213.

Mathre DM. 1992 - Gaemannomyces. In: Methods for research on soilborne phytopathogenic fungi. Singleton LL, Mihail JD, Rush CM (eds). APS Press. pp. 60-63.

Mathre DE, Johnson RH, Grey WE. 1998 - Biological control of take-all disease of wheat caused by Gaemannomyces graminis var. tritici under field conditions using a Phialophora sp. Biocontrol Science Technology 8, 449-457.

Mule G, Susca A, Stea G, Moretti A. 2004 - A species-specific PCR assay based on the calmodulin partial gene for identification of Fusarium verticillioides, $F$. proliferatum and $F$. subglutinans. European Journal of Plant Pathology 110, 495-502.

Nilsson HE. 1969 - Studies of root and foot rot diseases cereals and grasses, I on resistance to Ophiobolus graminis Sacc. Annals of the Agricultural College of Sweden 35, 275-807.

Peakall R, Smouse PE. 2006 - Genalex 6: genetic analysis in Excel. Population genetic software for teaching and research. Molecular Ecology Notes 6(1), 288-295.

Rachdowang S. 1999 - PCR-based test for differentiating varieties of Gaeumannomyces graminis, the take-all pathogen. Ph.D., Virginia Polytechnic Institute and State University. pp. 184

Safaei D, Sheikh-el-eslani M, Younesi H. 2007 - First report of Gaeumanomyces graminis in Kermanshah province. Nineteenth Congress of Plant Protection, Iran. pp. 285.

Thomas SL. 2004 - The development and utilization of assays to characterize populations of Gaeumannomyces graminis. Ph.D. The Ohio State.

Tilson EL, Pitt D, Fuller MP, Groenhof AC. 2005 - Compost increases yield and decreases take-all severity in winter wheat. Field Crops Research 94, 176-188.

Trolldenier G. 1981 - Influence of soil moisture, soil acidity and nitrogen source on take-all of wheat. Journal of Phytopathology 102, 163-177.

Weber Z, Irzykowska L, Bocianows J. 2005 - Analysis of mycelial growth rates and RAPD-PCR profiles in a population of Gaeumannomyces graminis var. tritici originating from wheat plants grown from fungicide-treated seed. Journal of Phytopathology 153, 318-325.

White JJ, Bruns T, Lee S, Taylor J. 1990 - Amplification and direct sequencing of fungal ribosomal RNA genes for phylogenetics. In: PCR Protocols: a guide to methods and applications (Innis MA, Gelfand DH, Sninsky JJ, White TJ eds). Sandiedo, CA, Academic Press. pp. 315-322. 